International Journal of English Language Studies (IJELS)

ISSN: 2707-7578

DOI: $10.32996 /$ ijels

Website: https://al-kindipublisher.com/index.php/ijels

IJELS

\title{
Evaluating the Textbook Used in the Greek Centre of Further Merchant Marine Education: School of Mechanics
}

\author{
Effrosyni K. Giannarou 8 (D) \\ M.Ed, Hellenic Open University School of Humanities, Postgraduate Study Program for Teachers of English as a Foreign \\ Language, Patras 2018, Greece \\ BA, Department of English Studies, University of Athens School of Philosophy 2000, Greece \\ $\triangle$ Corresponding Author: Effrosyni K. Giannarou, E-mail: frosgian@hotmail.com
}

ARTICLE INFORMATION
Received: February 12, 2021
Accepted: March 24, 2021
Volume: 3
Issue: 3
DOI: $10.32996 /$ ijels.2021.3.3.5

\section{KEYWORDS}

textbook evaluation, internal evaluation, external evaluation, marine engineers, training

\section{ABSTRACT}

This paper attempts to evaluate a teaching textbook used in the Greek Merchant Marine Center of Further Education: School of Mechanics. The evaluation considers adult learners' needs and practices to evaluate the prescribed textbook used in this institution. This textbook has been used for a long time and, though it includes proper ESP knowledge, it is considered to need embellishment to satisfy learners' growing needs, especially as it concerns engineering vocabulary. The research question mainly investigates whether this textbook helps learners in their practice of receptive and productive language skills both in general English and English for Specific Purposes use. Following a checklist of evaluation criteria, internal and external evaluation took place. It was found that the textbook is considered very plain and unattractive by learners. Though it includes the teaching of main vocabulary and grammar necessary to learners, it does not include material for pronunciation practice. Furthermore, it does not offer enough practise of all four language skills. It does not present activities for the practicing of vocabulary use or writing. There is also a lack of participatory tasks like group activities or teamwork. The findings contribute to the field because they could help embellish the teaching material with more communicative tasks and open-ended activities, which would motivate, interest, and engage learners more. The more purposeful use of technical language would be aiding mechanics in their training and in their work field in merchant navy vessels.

\section{Introduction}

Textbooks constitute an integral part of every teaching program. They are not simply tools used by teachers in their everyday teaching practice. They are not only a series of activities and tasks either. Instead, they are instruments that exhibit an underlying teaching and learning theory that influences teaching practice. This paper will evaluate Venardou, M, Tabakaki, M, Garby, M. (2007). English for Marine Engineers B Class, the official textbook used in the Merchant Marine Centre of Further Education: School of Mechanics. This institution is a Greek further education college that marine engineers attend to upgrade their professional diploma.

\section{Brief overview of textbook/ materials evaluation}

Before attempting to evaluate a textbook per se, teachers need to examine the teaching situation in which the textbook is used. First, they investigate and analyze student needs. Student needs include objective and subjective needs, learning styles, learning stages, motivation, interests etc. Teachers also need to be clear about the curriculum goals and the syllabus and finally identify their classroom constraints. Constraints usually include classroom size, time allocation, teacher competence etc (Ayakli, Karavas, 2004: 195).

Following the teaching situation analysis, teachers have to decide upon a number of criteria according to which the evaluation will be conducted. These criteria must be placed in order of priority and form criteria checklists.

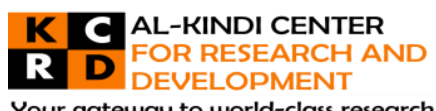

Your gateway to world-class research

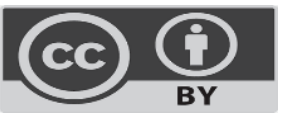

Published by Al-Kindi Center for Research and Development. Copyright (c) the author(s). This open access article is distributed under a Creative Commons Attribution (CC-BY) 4.0 license 
Checklists are a tool used to evaluate textbooks. They include a number of criteria according to which teachers judge teaching materials' effectiveness both externally and internally. Sheldon states that no checklist is appropriate for all teaching situations (Sheldon, 1987:241). This is why teachers have to create a checklist that incorporates the criteria that they feel to be suitable to their particular teaching situation.

In fact, Gearing (1998) mentions in an article that teachers should gather their textbook evaluation criteria in "concise" checklists and "apply a simple method of priority weighing".

As soon as teachers have prioritized their checklist criteria, they apply them in a tentative evaluation of their textbooks and reach a number of results.

It follows that textbook evaluation is both external and internal. External evaluation refers to the critical examination of a text book's external characteristics. These include the blurb, the contents page, the layout and illustrations (Ayakli, Karavas, 2004:196205) or, as Ansary and Babaii call them in an article, "the external criteria which give a broader view of the book" (Ansary, Babaii, 2002).

On the other hand, internal evaluation is a more in-depth examination of the materials. This includes the investigation into a text book's activities, skills practiced, language used, grading and sequencing of materials, subject and content (Ayakli, Karavas, 2004: 207-208, Aleni, Sadehvandi, 2012: 66).

Concerning textbook evaluation methods, provided that a teacher wishes his/her evaluation to be complete, s/he needs to evaluate textbook materials first 'as workplace. (Ayakli, Karavas, 2004: 215). This implies the evaluation of the material's theoretical value. Andrew Littlejohn argues that nowadays, due to UK publishers' presence all over the world, materials have increased in numbers and "effectively structure classroom time" (Littlejohn, 1998: 190-191).

Secondly, teaching materials need to be evaluated 'in process'. This means that the teacher critically evaluates the material effectiveness during the time that it is being taught in the classroom (formative evaluation). To do this, s/he records his/her and the students' reactions to the material. Finally, the teacher judges the teaching material's effectiveness by evaluating learner outcomes. This is a type of summative evaluation that attempts to round up what learners have gained from teaching with the aid of the teaching material under examination. In fact, in their book Evaluating the quality of learning, Biggs and Collis state that educators need to evaluate 'how much' and 'how well' a student has learned after being exposed to the 'learning episode' (Biggs, Collis, 1982:3).

\section{Brief description of the student group (needs) and teaching context (constraints)}

The student group who uses the text book under evaluation in this assignment consists of twenty adult marine engineers who attend a further education college to enhance their professional diploma. More precisely, the learners are third engineers who have to undertake two courses to receive the second engineer's diploma. English is a course offered in one of the two cycles of courses, and it is taught for seventy hours during a two-and-a-half month time period.

Learners need English that will help them in their work. The most important thing for them is to learn technical vocabulary that will help them in their work in the engine room, their communication with foreign crew, and their study of engine operation and maintenance manuals.

They are in favour of oral and group activities since their work presupposes being able to cooperate as a team. This entails much oral communication.

The teaching environment is quite traditional. The class contains rows of desks which are placed in parallel, they can be moved around, but there is little room to make any other arrangement. The curriculum dates back to the 1970s and is quite traditional, too since it emphasizes the teaching of grammar, writing letters, and the translation of technical manuals. Time is also a constraint for seventy hours are hardly enough to materialise a comprehensive course.

\section{Description of the textbook to be evaluated}

The textbook under evaluation in this assignment is called English for Marine Engineers B Class. It was published in 2007 and the authors are Venardou, M, Tabakaki, M, Garby, M.

The coursebook resembles more a collection of notes on technical texts and vocabulary than a textbook. There is no blurb, only a table of contents and some appendices at the end of the book containing a glossary and abbreviations. The external layout and illustration are pretty plain. The textbook is black and white and there is only a drawing of a vessel propeller on the cover page. 
More specifically, each unit contains a technical article followed by lists of vocabulary from the text and some "points of grammar". "Points of grammar" include grammar theory written in Greek and explaining the structure of English grammatical phenomena, such as how many kinds of nouns exist or how many articles there are in the English language. The textbook does not include any vocabulary or grammar tasks either. Only in one of the appendices is there a number of open-ended comprehension questions on all texts. This section is entitled "Questionnaire on texts" and aims to make learners go over all texts being studied to be reminded of the shapes and functions of various engine parts.

\section{Presentation and justification of textbook evaluation criteria}

The checklist developed for evaluating the text book English for Marine Engineers $B$ Class (see Appendix, page 11) contains questions that aim to evaluate both external and internal evaluations.

More specifically, the first part of the checklist contains questions related to the text book's 'Design and Organization'. They tackle the topics of textbook organization according to topic and structure, the textbook layout, the division in sections, and tasks. The list also contains questions relating to whether the textbook motivates learners to participate in a class or includes material for self-study and homework.

Another set of questions related to the coursebook external evaluation is the list referring to 'Teacher's books'. This list contains questions relating to the existence and effectiveness of teacher material.

The second part of the evaluation checklist contains questions related to internal evaluation. Adapted by Cunningsworth (1995 In Richards, 2012) and Grant (1987), internal evaluation questions refer to aspects like the 'Aims and Approaches' of the coursebook, its 'Language Content,' 'Skills practices,' 'Topics' and 'Methodology'. Here there is an attempt to assess whether the coursebook aims and approaches take the learning situation and learner needs under consideration. The checklist also examines whether textbook activities cater for the practice of all four receptive and productive skills. The language learning theory that the book adheres to is examined by questions in the section 'Methodology' while 'Topics' deal with vocabulary areas encountered by learners and the degree to which these are useful and interesting to them.

Finally, the section entitled 'Practical considerations' include questions relating to text book cost and availability.

The above checklist was structured in this way in an effort to examine many aspects relating the text book use and usefulness in the particular teaching context. It is a technical book and its aims and objectives are very specific. The design and general book organization is important because it should first attract learners but more importantly, it should cover as many knowledge areas as possible.

The text book's aims and approaches are important as well since they should be aligned with the official school curriculum. The language content and topics should be related to the naval engineering profession. The textbook should develop both receptive and productive skills since professional engineers need to understand general and technical English and produce written reports or participate in oral discussions or presentations related to their work. Textbook methodology is also tackled since it is essential for adult engineers to feel active in their learning. It has been found that passivity in engineering classes often leads to student failure and drop out (Felderm, Silverman, 1988: 674-681).

\section{Presentation of the main results of the evaluation}

The textbook evaluation checklist questions yielded a number of results. First of all, it was found that they course book is not very attractive. Its layout is simple, and it does not contain a blurb or a section with the justification of writers' choices. The coursebook layout makes it easy to study since it is quite plain. There are sections of grammar and vocabulary, but they are presented in the Greek language, and there are no practice activities.

Concerning the aims of the textbook, they are consistent with the aims of the official curriculum of the Merchant Marine Centre of Further Education: School of Mechanics. The curriculum and course aims are to teach learners technical vocabulary as well as basic grammatical structures so as to be able to understand written texts and manuals and to communicate with a foreign crew or explain the damage to service engineers whenever needed.

The textbook covers the main vocabulary and grammar items necessary to learners and suitable to the particular language content. It does not include material for pronunciation work though neither does it present language use conventions above the sentence level. It fails to offer learners practice in all skills since there is no material for integrated skills work. There are no speaking or writing activities (except for a few text- comprehension questions in one of the text book's appendices).

The material is interesting and useful to learners who can easily relate to the language use contexts therein presented. The topic presentation helps learners recognize particular language use situations and recall the necessary linguistic expressions or 
vocabulary when a similar situation arises. The problem here is that the textbook does not contain activities where the learners would practice these linguistic expressions or vocabulary either orally or in writing.

The coursebook adheres to the traditional grammar-translation method and the structural approach to language learning. Learners are not expected to participate in group activities.

Though it caters to a certain extent to objective learner needs since it presents a significant amount of marine engineering technical vocabulary necessary for their work, the coursebook does not really adhere to learner subjective needs since it does not incorporate tasks that would help learners practice what they learn. It includes neither oral nor written tasks. In fact, the way the textbook presents technical information reminds one of a long-lasting issue in technical education, that of the mismatch in learning and teaching styles.

According to Felder and Silverman (1988: 674-681), one problem in engineering classes is that the teaching material, as well as the professors, encourage learners to be passive. This is why the latter are usually bored. They do not do well in tests; they are discouraged and sometimes even drop out of classes. The authors claim that learners of all learning styles would benefit from courses designed around the principles of learner active involvement and inductive reasoning. Instead of being presented with facts or stale vocabulary items and grammar, the learners should discover the facts. In a similar fashion, textbook presentation of new vocabulary or grammar is not enough. It does not motivate learners. It would be much more preferable to introduce participatory tasks that would attract learner interest and enhance learning-by-doing.

\section{Conclusion}

The current study aimed at evaluating whether the textbook addressed learners' expectations and language needs related to their work field as merchant navy engineers. The content of the book was examined, its relation to the official curriculum was checked, and its presentation of technical vocabulary and grammar was investigated. It was found that the textbook items attracted the learners' interest but needed improvements primarily as it concerns the activities presented. Those should involve more teamwork and engage learners more in communication. Also, several technical language practices -both oral and writtenshould be done to feel that the learners feel that their communication skills could be improved. One limitation concerns the shortness of the training courses that do not last for more than a few months in this training center. It is not easy to arrive at safe conclusions regarding the textbook's or any other teaching materials' effectiveness within such a short time. Furthermore, learners constitute mixed ability groups since their English language speaking level is heterogeneous. Still, trying to satisfy the learners' needs and aspirations as to how they would like to learn the English language, could help them improve even within the short time of the official training.

\section{References}

[1] Alemi, M. Sadehvandi, N (2012). Textbook Evaluation: EFL Teachers' Perspectives on "Pacesetter Series". English Language Teaching (ELT), 1/7 (July), at www.ccsenet.org/journal/index.php/elt/article/view/18356/12153, accessed 8 April 2015.

[2] Ansary, H, Babaii, E (2002). Universal Characteristics of EFL/ESL Textbooks: A Step Towards Systematic Coursebook Evaluation'. The Internet TESL Journasl, 2002 at http://202.194.48/102/englishonline/jxyj/iteslj/index-25htm, accessed 8 April 2015.

[3] Ayakli, C, Karavas, K (2004). Course Design and Evaluation. Vol II. Patras: Hellenic Open University.

[4] Biggs, J.P, Collis, K.F. (1982). Evaluating the quality of learning. The SOLO Taxonomy (Structure of the Observed Learning Outcome). In Educational Psychology Series. London: Academic Press, Inc.

[5] Felder, R.M, Silverman, L.K (1988). Learning and Teaching Styles in Engineering Education'. Engineering Education. 78/7, 674-681

[6] Gearing, K. (1998). Helping less-experienced teachers of English to evaluate teachers' guides'. Oxford Journals: ELT Journal, 1/6 (June), at http://eltj.oxfordjournals.org/content/53/2/122.short, accessed 8 April 2015.

[7] Grant, N. (1987). Making the Most of your Textbook. London: Longman.

[8] Littlejohn, A. (1998). The analysis of language teaching materials: inside the Trojan Horse'. In B. Tomlinson (Ed), Materials Development in Language Teaching. Cambridge: Cambridge University Press, 190-191.

[9] Richards, J. K. (2012). Curriculum Development in Language Teaching. New York: Cambridge University Press.

[10] Sheldon, L.E. (ed). (1987). ELT Textbooks and Materials: Problems in Evaluation and Development. ELT Documents 126. Oxford: Modern English Publications, The British Council. 


\section{Appendix}

Course book used in the Merchant Marine Centre of Further Education in the School of Mechanics: Venardou, M, Tabakaki, M, Garby, M. (2007). English for Marine Engineers B Class

\section{Checklist for course book evaluation}

\section{External Evaluation}

Design and Organization

- Is the course book organized according to topics or structure?

- Does the course book layout make it easy to study it?

- Are there sections for grammar, vocabulary?

- Does the course book encourage/ motivate self study?

- Does the course book incorporate tasks that allow learners to practice vocabulary or grammar knowledge presented?

- Does the course book contain any activities for learners to take as homework?

- Does the course book include guides, references for further study?

- Is the course book appealing in appearance? Does it include sufficient blurb explaining its structure and the writers' choice of content?

Teachers' books

- Are there any teachers' books?

- Are keys to exercises given?

- Do the writers guide teachers who will be using the course book?

$\circ \quad$ Do the writers justify their choice of material?

\section{Internal Evaluation}

\section{Aims and Approaches}

- Are the aims of the course book in consistence with the aims of the curriculum of the Merchant Marine Centre of Further Education?

- Does the course book cater for learner objective and subjective needs?

- Can the text book easily be used in the learning context? Can it be suitably applied to the particular learning environment?

- Does the course book prescribe a specific teaching/ learning style? Does it allow for different teaching/ learning styles?

Language Content

\begin{tabular}{|c|c|c|c|}
\hline & YES & PARTLY & No \\
\hline $\begin{array}{l}\text { 1. Does the course book cover the main vocabulary and grammar items } \\
\text { necessary to learners? }\end{array}$ & & & \\
\hline $\begin{array}{l}\text { 2. Is material for vocabulary teaching adequate in terms of quantity and } \\
\text { suitable to the particular language context (marine English used in the } \\
\text { vessel engine room)? }\end{array}$ & & & \\
\hline $\begin{array}{l}\text { 3. Does the course book include material for pronunciation work? If so, } \\
\text { what is covered: individual sounds, word stress, sentence stress, } \\
\text { intonation? }\end{array}$ & & & \\
\hline $\begin{array}{l}\text { 4. Does the course book present the structuring and conventions of } \\
\text { language use above the sentence level? Does it encourage learners to } \\
\text { take part in conversations or to structure pieces of extended writing? }\end{array}$ & & & \\
\hline
\end{tabular}




\begin{tabular}{|l|l|l|l|}
\hline & YES & PARTLY & NO \\
\hline $\begin{array}{l}\text { 1. Does the course book include activities aiming at the practice of both } \\
\text { receptive (listening, reading) and productive (speaking, writing) } \\
\text { language skills? }\end{array}$ & & & \\
\hline 2. Is there material for integrated skills work? & & & \\
\hline 3. Is there sufficient reading material? & & \\
\hline $\begin{array}{l}\text { 4. Is there any listening material? If so, is it well recorded and does it } \\
\text { include questions and activities which help comprehension? }\end{array}$ & & \\
\hline $\begin{array}{l}\text { 5. Is there any well designed material for spoken English (dialogues, } \\
\text { role plays etc.) to equip learners for real life interactions? }\end{array}$ & & \\
\hline $\begin{array}{l}\text { 6. Are there any writing activities? Do they help learners in being } \\
\text { accurate, in organizing longer pieces of writing and in using } \\
\text { appropriate writing styles? }\end{array}$ & & & \\
\hline
\end{tabular}

Topic

- Is the material interesting and useful to learners?

- Are all vocabulary areas encountered by learners during their work covered?

- Can the learners relate to the language use contexts presented in the course book?

- Does the topic presentation help learners recognize particular situations of language use and recall the necessary linguistic expressions or vocabulary when a similar situation is encountered within their work field?

- Is communication with foreign crew members (e.g. the Phillippinese) referred to? Are other groups represented with reference to ethnic origin or work mentality/ methodology?

Methodology

- What approach to language learning does the course book adhere to? Is it appropriate to the teaching/learning situation and does it take into account learner needs and expectations?

- How much are learners expected to actively participate in the activities?

- What techniques are used for presenting/ practicing new language items? Do learners understand what they are being taught?

- Are different skills taught and how is this effectuated?

- How are communicative abilities structured?

- Are there any communicative activities in the course book and if so, are they adapted to the particular use context?

- Does the material advise students on how they should study and check their learning progress?

- Does the course book encourage students to set their own personal learning targets?

Practical considerations

- Does the course book have any economic cost or is it distributed for free to learners of a public educational institute like the Merchant Marine Centre of Further Education?

- How many parts does the course book consist of? Do any parts of the course book require special equipment such as a language laboratory or a video/ sound player?

- Should the course books run out, is it easy to obtain new ones at short notice?

Adapted by

Cunningsworth, A. (1995). Choosing your Coursebook. Oxford: Heinemann

Grant, N. (1987). Making the Most of your Textbook. London: Longman.

Richards, J.K. (2012). Curriculum Development in Language Teaching. New York: Cambridge University Press, pages $274-276$. 